\title{
PEMIKIRAN IBNU KHALDUN TENTANG MEKANISME PASAR
}

\author{
Oleh: Wulpiah ${ }^{1}$
}

\begin{abstract}
Ibnu Khaldun is a thought-leader who is proficient in the various fields of study such as politics, social, philosophy, history, and economy. So, Ibnu Khaldun is known as one of the originators of economic theory and as the largest Muslim economists recognized by Western economists. Unlike previous scholars who had tendencies to be normative, Ibnu Khaldun used bistorical and social approach to understand economy of a nation. Ibnu Khaldun was very positive in comprehending economy. So, his ways of thinking will be very worthy to put forward in this paper, especially on market mechanisms. Market is a place where buyers and sellers meet and do transactions of buying and selling goods or services. The importance of market in Islam cannot be separated from the function of the market as a place for buying and selling activities. Sale and purchase itself has an important function, since buying and selling are parts of the economic activities which are "accredited" in Islam. Islam is very concerned with buying and selling as one of the economic fundamentals. It can be seen in Al-Baqarah 275 saying that "God justifies the purchase and forbids usury". The market mechanism is a system that determines the formation of prices, which is in the process can be influenced by many things: demand and supply, distribution, government policies, labor, money, taxes and security. In the process of market mechanisms requires the principles of morality, such as fair competition (fair play), bonesty, transparency and justice.
\end{abstract}

Keywords: Ibn Khaldun, Market and Market Mechanism

\section{A. Pendahuluan}

Islam adalah agama yang selain bersifat syumuliyah (sempurna) juga harakiyah (dinamis). Sempurna karena Islam merupakan agama penyempurna dari agamaagama sebelumnya dan syari'atnya mengatur seluruh aspek kehidupan, baik yang bersifat aqidah maupun muamalah. Dalam kaidah muamalah, Islam mengatur segala bentuk perilaku manusia dalam berhubungan dengan sesamanya termasuk persoalan ekonomi.

Ekonomi sebagai kajian tentang perilaku manusia dalam hubungannya dengan pemanfaatan sumber-sumber produktif yang langka untuk memproduksi barang dan jasa-jasa serta mendistribusikannya untuk dikonsumsi. Ekonomi Islam

1 Jurusan Syariah dan dan Ekonomi Islam STAIN Syaikh Abdurahman Siddik Bangka Belitung, email: ulfii2015@gmail.com 
sebagai sebuah studi muncul pada tahun 1970-an. ${ }^{2}$ Rujukan utama ekonomi Islam adalah al-Qur'an dan Hadis. ${ }^{3}$ Ringkasnya pemikiran ekonomi Islam setua Islam itu sendiri. Walaupun sebagian besar diskursus ini hanya terkubur dalam literatur tafsir al-Qur'an, Hadis (termasuk syarabnya), fikih dan ushul fikih. Dan sekarang sudah ada usaha yang dilakukan untuk mengkaji lebih dalam materi-materi ini dan menyajikannya secara sistematis dan aktual, walaupun masih sedikit, terutama di Indonesia. ${ }^{4}$ Dengan demikian membangun pemikiran ekonomi Islam ini menjadi penting untuk dilakukan dan kerja berjamaah, artinya tidak hanya oleh ekonom saja, tapi juga oleh fukaha, mufassir dan sebagainya walaupun sudut pandang dan pendekatannya bisa berbeda.

Dalam lintasan sejarah umat Islam, di dapati banyak sekali tokoh yang mendiskusikan tentang persoalan ekonomi yang secara sosiologis turut membangun teori-teori/konsep ekonomi, seperti Abu Yusuf (w.182 H), Yahya bin Adam (w.303 H), Al-Ghozali (w.505 H), Ibnu Rusyd (w.595 H), al-Izz bin, Abdis Salam (w.660 H), al-Farabi (w.339H), Ibnu Taymiyah (w.728 H), Ibnu Khaldun (w.808 H), al-Maqrizi (w.845 H), dan lain-lain. Salah satu tokoh yang concern membahas tentang mekanisme pasar adalah Ibnu Khaldun.

\section{B. Pembahasan}

\section{Sejarah Kelahiran Ibnu Khaldun}

Ibnu Khaldun ${ }^{5}$ nama lengkapnya adalah Abd al-Rahman bin Muhammad bin Khaldun al-Hadrawi, dikenal dengan panggilan Waliyuddin Abu Zaid, Qadi al-Qudat. Ia lahir tahun $732 \mathrm{H}$ di Tunis. Ia bermazhab Maliki, Muhadist al-Hafidz, pakar ushul fiqh, sejarawan, pelancong, penulis dan sastrawan. Saat kecil ia biasa dipanggil dengan

2 MB. Hendrie Anto, Pengantar Ekonomika Mikro Islam, Cet.I, (Yogyakarta, Ekonisia, 2003), hal. 69. Lihat juga M. Dawam Rahardjo, "Menegakkean Syariat Islam di Bidang Ekonomi", dalam Adiwarman Karim, Bank Islam: Analisis Fikih dan Keuangan, Cet.I, (Jakarta, IIIT, 2003), hal. xvii.

${ }_{3}^{3}$ M. Abdul Mannan, Teori dan Praktek Ekonomi Islam, terj. M. Nastangin, (Yogyakarta, Dana Bhakti Wakaf, 1995), hal. 29-33.

${ }^{4}$ Dalam Tulisan MB. Hendrie Anto, Pengantar...,hal. 69, Tulisan Adiwarman Karim, Ekonomi Mikro Islami, (Jakarta, Cet III, 2002), Adiwarman Karim, Ekonomi Islam: Suatu Kajian Ekonomi Makro, (Jakarta, Cet. III, 2002), lihat juga Mustafa Edwin Nasution, et al., Pengenalan Eksklusif Ekonomi Islam, (Jakarta, Kencana Prenada Media Group, 2006), juga M. Syafi'i Antonio, Bank Syariab: Dari Teori ke Praktik, (Jakarta, Gema Insani Press, 2001), juga Eko Supryitno, Ekonomi Islam: Pendekatan Ekonomi Makro Islam dan Konvensional, (Yogyakarta, Penerbit Graha Ilmu, 2005)

5 Zainal al-Khudhairi, Filsafat Sejarah Ibn Khaldun, Pent. Ahmad Rafi' Usmani, (Bandung : Penerbit Putaka, 1987), hal. 9 
nama Abdurrahman. Sedangkan Ibnu Zaid adalah panggilan keluarganya. Ia bergelar waliyudin dan nama populernya adalah Ibnu Khaldun. Gelar waliyudin merupakan gelar yang diberikan orang sewaktu Ibnu Khaldun memangku jabatan hakim (qadli) di Mesir. Sebutan 'alamah didepan namanya menunjukkan bahwa pemakai gelar tersebut merupakan orang yang mempunyai gelar kesarjanaan tertinggi, sebagaimana gelar-gelar yang lain, seperti Rais, al-Hajib, al-Shadrul, al-Kabir, al-Faqih, al-Jalil dan Imamul A'immah, Jamal al-Islam wa al-Muslimin. Mengenai tambahan nama belakangnya, al-Maliki, ini dihubungkan dengan imam mazhab yang dianutnya dalam ilmu fiqh, yaitu mazhab Imam Malik bin Anas. Nenek moyangnya berasal dari Hadramaut yang kemudian berimigrasi ke Seville (Spanyol) pada abad ke-8 setelah semenanjung itu dikuasai Arab muslim. Keluarga yang dikenal pro Umayah ini selama berabad-abad menduduki posisi tinggi dalam politik di Spanyol, sampai akhirnya hijrah ke Maroko beberapa tahun sebelum Seville jatuh ke tangan Kristen pada 1248 M. Setelah itu mereka menetap di Tunisia. Di kota ini mereka dihormati oleh pihak istana, diberi tanah milik dinasti Hafsiah. Latar belakang keluarga dari kelas atas ini rupanya menjadi salah satu faktor penting yang kemudian mewarnai karir hidup Ibnu Khaldun dalam politik sebelum ia terjun sepenuhnya ke dunia ilmu. Otak cerdas yang dimilikinya jelas turut bertanggung jawab mengapa ia tidak puas bila tetap berada di bawah. Orientasi ke atas inilah yang mendorongnya untuk terlibat dalam berbagai intrik politik yang melelahkan di Afrika Utara dan Spanyol.

Ibnu Khaldun ${ }^{6}$ dibesarkan dalam keluarga ulama dan terkemuka. Dari ayahnya ia belajar ilmu qiro'at. Sementara ilmu hadits, bahasa Arab dan fiqh diperoleh dari para gurunya, Abu al-Abbas al-Qassar dan Muhammad bin Jabir alRawi. Ia juga belajar kepada Ibn 'Abd al-Salam, Abu Abdullah bin Haidarah, al-Sibti dan Ibnu 'Abd al-Muhaimin. Kemudian memperoleh ijazah hadits dari Abu al-Abbas al-Zawawi, Abu Abdullah al-Iyli, Abu Abdullah Muhammad, dan lain-lain. Ia pernah mengunjungi Andalusia dan Maroko. Di kedua negara itu ia sempat menimba ilmu dari para ulamanya, antara lain Abu Abdullah Muhammad al-Muqri, Abu al-Qosim Muhammad bin Muhammad al-Burji, Abu al-Qasim al-Syarif al-Sibti, dan lain- lain. Kemudian mengunjungi Persia, Granada, dan Tilimsin. Banyak tokoh dan ulama

\footnotetext{
${ }^{6}$ Ahmad Syafi'i Ma"earif, Ibnu Khaldun dalam Pandangan Penulis Barat dan Timur, (Jakarta: Gema Insani Press, 1996), hal. 12.
} 
yang menjadi muridnya. Mereka antara lain Ibnu Marzuq al-Hafidz, al-Damamini, alBusili, al-Bisati Ibnu Ammar, Ibnu Hajar, dan lain-lain. Dalam usia muda Ibnu Khaldun sudah menguasai beberapa disiplin ilmu Islam klasik, termasuk 'ulum aqliyah (ilmu-ilmu kefilsafatan, tasawuf dan metafisika). Di bidang hukum, ia mengikuti mazhab Maliki. Di samping itu semua, ia juga tertarik pada ilmu politik, sejarah, ekonomi, geografi dan lain-lain.

Otaknya memang tidak puas dengan satu dua disiplin ilmu saja. Di sinilah terletak kekuatan dan sekaligus kelemahan Ibnu Khaldun. Pengetahuannya begitu luas dan bervariasi ibarat sebuah ensiklopedi. Namun dari catatan sejarah, ia tidak dikenal sebagai seorang yang sangat menguasai satu bidang disiplin. Karya-karya Ibnu Khaldun, termasuk karya-karya yang monumental. Ibnu Khaldun menulis banyak buku, antara lain; Syarh al-Burdah, sejumlah ringkasan atas buku-buku karya Ibnu Rusyd, sebuah catatan atas buku Mantiq, ringkasan (mukhtasor) kitab al-Mahsul karya Fakhr al-Din al-Razi (Ushul Fiqh), sebuah buku lain tentang matematika, sebuah buku lain lagi tentang ushul fiqh dan buku sejarah yang sangat dikenal luas. Buku sejarah tersebut berjudul al-Ibar wa Diwan al-Mubtada' wa al-Khabar fi Tarikh al-Arab wa al-Ajam wa al-Barbar. Ibnu Khaldun melalui buku ini benar-benar menunjukkan penguasaannya atas sejarah dan berbagai bidang ilmu pengetahuan. Di samping kitab tersebut, kitab al-Muqoddimah Ibnu Khaldun merupakan karya monumental yang mengundang para pakar untuk meneliti dan mengkajinya. Tokoh ini meninggal dunia secara mendadak di Kairo pada tahun $807 \mathrm{H}$ dan dimakamkan di kuburan kaum sufi di luar Bab al-Nasr.

Karir hidup yang penuh gejolak masa kecil dan awal masa mudanya tidak diketahui secara rinci. Namun sebagai bagian dari keluarga elit, Ibnu Khaldun telah aktif dalam kegiatan intelektual di kota kelahirannya, disamping mengikuti dari dekat kehidupan politik. Neneknya pernah menjabat menteri keuangan Tunisia, sementara ayahnya sendiri adalah seorang administrator dan perwira militer, meskipun kemudian mengundurkan diri agat dapat memusatkan perhatian kepada dunia ilmu hukum, teologi dan sastra. Sampai ia wafat karena penyakit menular yang terkenal dengan sebutan the black death pada 1349, pada saat Ibnu Khaldun berusia 17 tahun.

${ }^{7}$ Baca Secara Lengkap di Muhsin Mahdi, Ibnu Khaldun's Philosophy of History, (Chicago: The University of Chicago Press, 1971), hal. 27-29 
Jauh sebelum menulis di al-Muqaddimah ${ }^{8}$, Ibnu Khaldun, sebagaimana telah disinggung di atas, telah terlibat dalam intrik politik. Itu terjadi bahkan sebelum berusia 20 tahun. Kenyataan ini menjelaskan kepada kita bahwa sejak awal ia sudah mengamati bagamana kiprah orang dalam politik.

Pada usia 18 tahun terjadi suatu peristiwa penting yang menyebabkannya berhenti belajar. Pada tahun $749 \mathrm{H}$ disebagian besar belahan dunia timur dan bagian barat yang meliputi negara-negara Islam di Samarkand hingga Mghribi dan Italia, Sebagian besar negara-negara Eropa dan Andalusia terjangkit wabah penyakit pes. Penyakit tersebut menyebabkan kedua orang tua Ibn Khaldun dan beberapa Syeikhnya meninggal dunia. Akibatnya, penguasa bersama-sama para ulama yang masih hidup ke Maghrib jauh (Maroko) pada tahun $750 \mathrm{H}$. Pekerjaan pertama Ibnu Khaldun adalah Kitabah al-'alamah atau penulis kata-kata Alhamdulillah dan AsySyukrillah diantara tulisan basmallah dan isi surat selanjutnya. Pekerjaan ini ia peroleh pada masa pemerintahan Abu Muhammad Ibnu Tafkarin di Tunisia. Karya a. Kitab al-'Ibar Nama lengkap dari kitab ini adalah Kitab al-'Ibar wa Diwa al-Mubtada' wa al-Khabar fi al-A'jam wa al-Barbar wa man 'Asrahum min Zawi as-sultan AlAkbar. Karya Ibnu Khaldun di bidang sejarah terdiri dari tujuh jilis yang meliputi tiga buku. Buku yang pertama terdiri dari satu jilid adalah Kitab al-Muqaddimah yang khusus memuat pembahasan tentang gejala-gejala sosial dan persoalan umat dan ekonomi Islam.

\section{Perspektif Ekonom tentang Harga dan Pasar}

Perspektif ekonomi konvensional, Philip Kotler harga ${ }^{9}$ adalah salah satu unsur bauran pemasaran yang menghasilkan pendapatan; unsur-unsur lainnya menghasilkan biaya. Harga adalah unsur bauran pemasaran yang paling mudah disesuaikan; ciri-ciri produk, saluran, bahkan promosi membutuhkan lebih banyak waktu. Harga juga mengkomunikasikan posisi nilai yang dimaksudkan perusahaan tersebut kepada pasar tentang produk dan brand-nya. Dapat dijelaskan dari pengertian di atas bahwa unsur-unsur bauran pemasaran yang dimaksud adalah harga, produk,

${ }^{8}$ Muqaddimah adalah salah satu bagian dari karya terbesar Ibnu Khaldun dalam Kitab al-Ibar wa Diwan al-Mubtada' wa al-Akbbar fi Tarikh al-Arab wa al-'Ajam wa al-Barbar. karya ini terdiri dari tiga buah buku yang terbagi dalam tujuh volume, yakni Mukaddimah (satu volume), al-Ibar (4 volume) dan al-Ta'rif (2 volume). Lihat Adiwarman Karim, Sejarah Pemikiran Ekonomi Islam, hal. 393

${ }^{9}$ Kotler, Manajemen Pemasaran, (Edisi XI) Jilid 2, (Jakarta : Gramedia, 2005), hal. 139. 
saluran dan promosi, yaitu apa yang dikenal dengan istilah empat P (Price, Product, Place dan Promotion).

Adam Smith ${ }^{10}$ menjelaskan dalam bukunya Wealth of Nations sebagai berikut :

The natural price, therefore, is, as it were, the central price, to which the prices of all commodities are continually gravitating. Different accidents may sometimes keep them suspended a good deal above it, and sometimes force them down even somewhat below it. But whatever may be the obstacles which binder them from settling in this centre of repose and continuance, they are constantly tending towards it. Artinya : Harga alamiah, oleh karenanya disebut juga, harga pusat, dimana harga semua komoditas cenderung berubah. Kecelakaan yang berbeda kadang-kadang membuat mereka menunda kesepakatan yang baik di atasnya, dan kadang-kadang memaksa mereka turun bahkan sedikit di bawah itu. Tapi apa pun kemungkinan jenis hambatan yang menghalangi mereka untuk menetap di pusat ketenangan ini dan kelanjutannya, mereka terus- menerus cenderung ke arah itu.

Selanjutnya perspektif Islam tentang harga, Rachmat Syafei ${ }^{11}$ menjelaskan bahwa harga hanya terjadi pada akad, yakni sesuatu yang direlakan dalam akad, baik lebih sedikit, lebih besar, atau sama dengan nilai barang. Biasanya, harga dijadikan penukar barang yang diridhai oleh kedua pihak yang melakukan akad. Dari pengertian di atas dapat dijelaskan bahwa harga merupakan kesepakatan mengenai transaksi jual beli barang/jasa di mana kesepakatan tersebut diridhai oleh kedua belah pihak. Harga tersebut haruslah direlakan oleh kedua belah pihak dalam akad, baik lebih sedikit, lebih besar, atau sama dengan nilai barang/jasa yang ditawarkan oleh pihak penjual kepada pihak pembeli. Menurut Ibnu Taimiyah yang dikutip oleh Yusuf Qardhawi: ${ }^{12}$ "Penentuan harga mempunyai dua bentuk; ada yang boleh dan ada yang haram. Tas'ir ada yang zhalim, itulah yang diharamkan dan ada yang adil, itulah yang dibolehkan."

Dalam konsep Islam, cara pengendalian harga ditentukan oleh penyebabnya. Bila penyebabnya adalah perubahan pada permintaan dan penawaran, maka mekanisme pengendalian dilakukan melalui intervensi pasar. Bila penyebabnya adalah distorsi terhadap permintaan dan penawaran, maka pengendalian dilakukan dengan menghilangkan distorsi tersebut. Intervensi pasar menjadi sangat penting dalam

${ }^{10}$ Jim Manis, An Inquiry into the Nature and Causes of the Wealth of Nations by Adam Smith, (Hazleton : 2005, The Pennsylvania State University), hal, 51

${ }^{11}$ Rachmat Syafei, Fiqih Muamalah (Bandung: Pustaka Setia, 2000) hal.87

${ }^{12}$ Yusuf Qardhawi, Norma Dan Etika Ekonomi Islam (Jakarta: Gema Insani, 1997) hal.257 
menjamin ketersediaan barang kebutuhan masyarakat. Dalam keadaan kekurangan barang kebutuhan pokok, pemerintah dapat membuat aturan agar pedagang tidak menjual barang ke luar wilayah, ataupun dengan membuat kebijakan agar produsen meningkatkan produksinya guna meningkatkan jumlah kebutuhan pokok di pasar. Inilah bentuk peran negara dalam mekanisme pasar sebagai regulator, mengawasi dan mengatur mekanisme pasar agar berjalan seimbang, sehingga tercipta harga yang adil (equilibrium price) yaitu harga yang tidak menimbulkan dampak negatif ataupun kerugian bagi para penjual maupun pembeli.

Ada beberapa faktor yang membolehkan intervensi harga, yaitu sebagai berikut:

a. Intervensi harga menyangkut kepentingan masyarakat yaitu melindungi penjual dalam hal profit margin (keuntungan), dan pembeli dalam hal purchasing power (kemampuan pembeli). Jika harga tidak ditetapkan ketika penjual menjual dengan harga tinggi yang dapat merugikan pembeli

b. Intervensi harga mencegah ikhtikar atau ghaban fâhisy.

c. Intervensi harga melindungi kepentingan masyarakat yang lebih luas karena pembeli biasanya mewakili masyarakat yang lebih luas.

Ibnu Khaldun mengakui adanya pengaruh antara permintaan dengan penawaran dalam membentuk harga. Untuk itu, dia menawarkan konsep harga moderat, dimana harganya memang tidak memberatkan konsumen dan tidak merugikan produsen. Harga yang moderat bisa mendorong kesejahteraan bersama. Meski demikian, untuk rakyat miskin harus disubsidi dengan diberikan harga yang lebih rendah dari harga pasar. ${ }^{13}$

Ibnu Khaldun ${ }^{14}$ dalam kitab Muqaddimah-nya menulis satu bab yang secara khusus membahas mengenai mekanisme harga, bab tersebut berjudul 'harga-harga di kota'. Franz Rosentha ${ }^{15}$ yang menerjemahkan buku Muqaddimah karya Ibnu Khaldun menjadi The Muqaddimah: An Introduction to History, ia menerjemahkan:

13 Ibnu Khaldun. Muqaddimah. Terj. Ahmadie Thoha. (2000. Pustaka Firdaus, Jakarta). hal.

${ }^{14}$ Ulfa Jamilatul Farida, 'Telaah Kritis Pemikiran Ekonomi Islam Terhadap Mekanisme Pasar Dalam Konteks Ekonomi Islam Kekinian' dalam La-Riba-Jurnal Ekonomi Islam, (Sleman: Universitas Islam Indonesia, 2012), hal. 257-270

15 Franz Rozenthal, Ibnu Khaldun the Muqaddimah, An Introduction to History, (London: Routledge \& Kegan Paul, 1958), hal. 283. 
Then, when a city has a highly developed, abundant civilization and is full of luxuries, there is a verylarge demand for those conveniences and for having as many of them as a personcan expect in view of his situation. This results in a very great shortage of suchthings. Many will bid for them, but they will be in short supply. They will be needed for many purposes, and prosperous people used to luxuries will pay exorbitant prices for them, because they need them more than others. Thus, as one can see, pricescome to be bigh.

Artinya : Sesungguhnya apabila sebuah kota telah makmur dan berkembang serta penuh dengan kemewahan, maka di situ akan timbul permintaan (demand) yang besar terhadap barang-barang. Tiap orang membeli barangbarang mewah itu menurut kesanggupannya. Maka barang-barang menjadi kurang. Jumlah pembeli meningkat, sementara persediaan menjadi sedikit. Sedangkan orang kaya berani membayar dengan harga tinggi untuk barang itu, sebab kebutuhan mereka makin besar. Hal ini akan menyebabkan meningkatnya harga sebagaimana anda lihat.

Menurut Ibnu Khaldun ${ }^{16}$ dalam menentukan harga di pasar atas sebuah produksi, faktor yang sangat berpengaruh adalah permintaan dan penawaran. Menurutnya apabila sebuah kota berkembang dengan pesat, mengalami kemajuan dan penduduknya padat, maka persedian bahan makanan pokok melimpah. Hal ini dapat diartikan bahwa penawaran yang meningkat mengakibatkan harga bahan/barang pokok tersebut murah. Seperti ditulis dalam The Muqaddimah:

An introduction to History: "When a city is highly developed and has many inhabitants, the prices of necessary foodstuffs and corresponding items are low..." Artinya : Ketika sebuah kota yang sangat maju dan memiliki banyak, penduduk, harga bahan makanan dan barang-barang yang diperlukan menjadi rendab/ murah ...

Ibnu Khaldun ${ }^{17}$ menekankan bahwa kenaikan penawaran atau penurunan permintaan menyebabkan kenaikan harga, demikian pula sebaliknya kenaikan permintaan atau penurunan penawaran akan menyebabkan penurunan harga. Analisa supply and demand Ibnu Khaldun tersebut di dalam ilmu ekonomi modern, diteorikan sebagai terjadinya peningkatan disposable income (kelebihan pendapatan) dari penduduk kota. Naiknya hal tersebut dapat menyebabkan naiknya marginal propersity to consume (kecenderungan marginal untuk mengkonsumsi) dari setiap penduduk kota terhadap barang mewah. Hal ini menciptakan kebutuhan baru atau peningkatan permintaan

\footnotetext{
${ }^{16}$ Chamid, Jejak Langkah Sejarah Pemikiran Ekonomi Islam, hal. 251

${ }^{17}$ Agustianto,"Pemikiran Ekonomi Ibnu Khaldun," 
terhadap barang-barang mewah. Akibatnya harga barang-barang mewah akan meningkat dengan sendirinya. Adanya kecenderungan tersebut dikarenakan oleh terjadinya disposable income penduduk kota seiring dengan berkembangnya kota itu.

Analisa Ibnu Khaldun tentang harga tersebut yang dirumuskan menggunakan hukum supply and demand luar biasa di zamannya, karena terjadi jauh sebelum para ekonom konvensional seperti Adam Smith, David Ricardo dkk merumuskan teori tersebut. Dari kalimat pertama Ibnu Khaldun di atas dijelaskan bahwa pasar adalah tempat yang menyediakan kebutuhan manusia, baik itu kebutuhan primer, sekunder maupun tertier. Ibnu Khaldun juga menjelaskan akibat dari adanya pungutan dan pajak terhadap meningkatnya biaya produksi barang.

Dari penjelasan di atas akibat adanya pungutan dan pajak atas bea masuk barang ke kota mengakibatkan harga barang di kota menjadi lebih mahal daripada di desa. Dijelaskan oleh Ibnu Khaldun pengaruh pajak terhadap harga-harga. Harga damai begitu istilah menyebutkan, sangat dibutuhkan oleh pedagang dan konsumen. Karena bila harga turun terlalu drastis maka pedagang akan dirugikan dan mendorong mereka keluar dari pasar. Sedangkan ketika harga naik keterlaluan, maka konsumen yang akan mengalami kerugian dan kesusahan.

\section{Pemikiran Ibnu Khaldun tentang Mekanisme Pasar}

Pada dasarnya dalam sistem ekonomi Islam, mekanisme pasar $^{18}$ dibangun atas dasar kebebasan, yakni kebebasan individu untuk melakukan transaksi barang dan jasa. Sistem ekonomi Islam menempatkan kebebasan pada posisi yang tinggi dalam kegiatan ekonomi, walaupun kebebasan itu bukanlah kebebasan mutlak seperti yang dianut paham kapitalis. Namun, kebebasan itu diikat dengan aturan, dengan tidak melakukan kegiatan ekonomi yang bertentangan dengan aturan syariat, tidak menimbulkan kerugian bagi para pihak yang bertransaksi, dan senantiasa melakukan kegiatan ekonomi dalam rangka mewujudkan kemaslahatan. Pemikiran tentang mekanisme pasar, sudah menjadi perhatian para ulama klasik, beribu-ribu tahun yang

${ }_{17}$ Pusat Pengkajian dan Pengembangan Ekonomi Islam (P3EI), Ekonomi Islam, Jakarta : Rajawali Pers, 2009), hal 302 dan Mustafa Edwin Nasution, Pengenalan Eksklusif Ekonomi Islam, (Jakarta : Kencana, 2007), hal 158 
lalu, seperti Abu Yusuf (731-798), Al-Ghazali (1058-1111), Ibnu Taimiyah (12631328), Ibnu Khaldun (1332-1383).

Pasar adalah sebuah mekanisme pertukaran produk baik berupa barang maupun jasa yang alamiah dan telah berlangsung sejak awal peradaban manusia. Islam menempatkan pasar pada kedudukan yang penting dalam perekonomian. Kegiatan ekonomi pada masa Rasulullah dan Khulafaur Rasyidin menunjukkan adanya peranan pasar dalam pembentukan masyarakat Islam pada masa itu. Rasulullah sangat menghargai harga yang dibentuk oleh mekanisme pasar sebagai harga yang adil. Beliau menolak adanya intervensi harga seandainya perubahan harga terjadi karena mekanisme pasar yang wajar yaitu hanya karena pergeseran permintaan dan penawaran. Namun, pasar di sini mengharuskan adanya moralitas dalam kegiatan ekonominya, antara lain persaingan yang sehat dan adil, kejujuran, keterbukaan, dan keadilan. Jika nilai ini telah ditegakkan, maka tidak ada alasan dalam ekonomi Islam untuk menolak harga yang terbentuk oleh mekanisme di pasar. ${ }^{19}$

Pasar juga merupakan tempat untuk beraktifitas ekonomi dimana kegiatan ekonomi berlangsung secara alamiah sehingga aturan mainnya pun terjadi secara alamiah. Sehingga menurut ekonomi Islam, mekanisme pasar dapat terjadi secara alamiah dari sisi penawaran dan permintaan sebagaimana mestinya. Selanjutnya, mekanisme pasar perspektif ekonomi Islam pada prinsipnya adalah menolak adanya suatu price intervention seandainya perubahan harga terjadi karena mekanisme pasar yang wajar. Namun, pasar di sini mengharuskan adanya moralitas, antara lain persaingan yang sehat (fair play), kejujuran (bonesty), keterbukaan (transparancy), dan keadilan (justice). Jika nilai-nilai ini telah ditegakkan, maka tidak ada alasan untuk menolak harga pasar. Dan jika terjadi penyimpangan maka kewajiban negara untuk mengaturnya demi kemaslahatan umat.

Pentingnya pasar sebagai wadah aktifitas tempat jual beli tidak hanya dilihat dari fungsinya secara fisik, namun aturan, norma dan yang terkait dengan masalah pasar. Dengan fungsi di atas, pasar jadi rentan dengan sejumlah kecurangan dan juga perbuatan ketidakadilan yang menzalimi pihak lain. Karena peran pasar penting dan juga rentan dengan hal-hal yang zhalim, maka pasar tidak terlepas dengan sejumlah

19 Ali Hasan, Manajemen Bisnis Syariah : Kaya di Dunia Terhormat di Akherat, Yogyakarta : Pustaka Pelajar, 2009), hal. 4 
aturan syariat, antara lain terkait dengan pembentukan harga dan terjadinya transaksi di pasar. Dalam istilah lain dapat disebut sebagai mekanisme pasar menurut Islam dan intervensi pemerintah dalam pengendalian harga. Pentingnya pembahasan pemikiran Ibnu Khaldun tentang ekonomi karena pemikirannya memiliki signifikansi yang besar bagi pengembangan ekonomi Islam ke depan. ${ }^{20}$

Berbicara mengenai mekanisme pasar dalam dasar hukum Islam yang pertama yaitu al Qur'an, tentu saja al Qur'an sebagai dasar filosofi hidup manusia tidak memberikan aturan secara jelas tentang apa itu mekanisme pasar. Namun demikian sebagai manusia yang dilengkapi akal maka kita akan dapatkan aturan main tentang pasar yaitu seperti apa yang tersebut dalam al Qur'an surat an-Nisa (4) ayat 29, sebagai berikut:

"Hai orang-orang yang beriman, janganlah kamu saling memakan harta sesamamu dengan jalan yang batil, kecuali dengan jalan perniagaan yang berlaku dengan suka sama-suka di antara kamu. Dan janganlah kamu membunuh dirimu. Sesungguhnya Allah adalah Maha Penyayang kepadamu." (Q.S. An-Nisa: 29)

M. Quraish Shihab ${ }^{21}$ dalam tafsirnya al-Misbah menafsirkan ayat tersebut (QS. An-Nisa (4): 29) sebagai berikut. Dalam konteks ekonomi, ayat tersebut menyebutkan beberapa prinsip penting dalam berekonomi. Pertama, kata yang dimaksud adalah harta yang beredar dalam masyarakat. Kedua, yakni pelanggaran terhadap ketentuan agama atau persyaratan yang disepakati. Dalam konteks ini, nabi Muhammad saw. Bersabda, "Kaum muslimin sesuai dengan (harus menepati) syaratsyarat yang mereka sepakati, selama tidak menghalalkan yang haram atau mengharamkan yang halal". Dan selanjutnya kata yang mengharuskan adanya kerelaan kedua belah pihak yaitu larangan membunuh diri sendiri mencakup juga larangan membunuh orang lain, sebab membunuh orang lain berarti membunuh diri sendiri karena umat merupakan suatu kesatuan. Prinsip 'antara dhin minkum, walaupun kerelaan merupakan hal yang tersembunyi di dalam hati, tetapi indikator dan tandatandanya dapat terlihat. Ijab dan kabul, atau apa saja yang dikenal dalam adat kebiasaan sebagai serah terima adalah bentuk-bentuk yang digunakan hukum untuk

20 Sutan Remy Sjahdeini, Perbankan Syariah : Produk-Produk dan Aspek Hukumnya,(Jakarta : Kencana Prenada Media Group, 2014), hal.21.

${ }^{21}$ M. Quraish Shihab, Tafsir al Misbah (Jakarta: Lentera Hati, 2002), hal. 412. 
menunjukkan kerelaan. Dari tafsir ayat an-Nisa (4): 29 tersebut jelas apa yang menjadi prinsip dasar aktifitas pasar. Selanjutnya bagaimana pasar atau mekanisme pasar pada masa Nabi?

Pasar pada masa Rasulullah Muhammad saw. Pasar memegang peranan penting dalam perekonomian masyarakat muslim pada masa Rasulullah SAW dan Khulafaurrasyidin. Bahkan, Muhammad SAW sendiri pada awalnya adalah seorang pebisnis, demikian pula Khulafaurrasyidin dan kebanyakan sahabat. Pada saat awal perkembangan Islam di Makkah Rasulullah SAW dan masyarakat muslim mendapat gangguan dan teror yang berat dari masyarakat kafir Makkah sehingga perjuangan dan dakwah merupakan prioritas. Ketika masyarakat muslim telah berhijrah ke Madinah, peran Rasulullah SAW bergeser menjadi pengawas pasar atau al-Muhtasib. Pada saat itu mekanisme pasar sangat dihargai. Beliau menolak untuk membuat kebijakan penetapan harga manakala tingkat harga di Madinah pada saat itu tiba-tiba naik. Sepanjang kenaikan terjadi karena kekuatan permintaan dan penawaran yang murni, yang tidak dibarengi dengan dorongan-dorongan monopilistik dan monopsonistik, maka tidak ada alasan untuk tidak menghormati harga pasar.

Dalam suatu Hadits dijelaskan bahwa pasar merupakan hukum alam (Sunnatullab) yang harus dijunjung tinggi. Tak seorang pun secara individual dapat mempengaruhi pasar, sebab pasar adalah kekuatan kolektif yang telah menjadi ketentuan Allah SWT. Pelanggaran terhadap harga pasar, misalnya penetapan harga dengan cara dan karena alasan yang tidak tepat, merupakan suatu ketidakadilan (injustice) yang akan dituntut pertanggung jawabannya dihadapan Allah dan begitu pun sebaliknya. Penghargaan Islam terhadap mekanisme pasar berdasar pada ketentuan Allah SWT bahwa perniagaan harus dilakukan secara baik dengan rasa suka sama suka serta nilai moralitas mutlak harus ditegakkan. Secara khusus nilai moralitas yang mendapat perhatian penting dalam pasar adalah persaingan yang sehat, kejujuran, keterbukaan, dan keadilan.

Mekanisme pasar ${ }^{22}$ adalah sebuah sistem yang menentukan terbentuknya harga, yang di dalam prosesnya dapat dipengaruhi oleh berbagai hal yaitu permintaan

22 Pusat Penelitian dan Pengkajian Ekonomi Islam, Ekonomi Islam, (Jakarta : Rajawali Pers, 2012), hal. 301 
dan penawaran, distribusi, kebijakan pemerintah, pekerja, uang, pajak dan keamanan. Dalam proses mekanisme pasar tersebut diharuskan adanya asas moralitas, antara lain persaingan yang sehat (fair play), kejujuran (bonesty), keterbukaan (transparancy), dan keadilan (justice).

Pada prinsipnya mekanisme pasar diartikan bahwa harga bergerak bebas sesuai hukum permintaan dan penawaran (supply and demand). Jika supply lebih besar dari demand, maka harga akan cenderung rendah. Begitupun jika demand lebih tinggi sementara supply terbatas, maka harga akan cenderung mengalami peningkatan. Dalam implementasi sehari-hari belum bisa dipastikan kegiatan yang terbentuk di pasar apakah memang berjalan sesuai dengan mekanisme pasar yang wajar, tidak ada unsur intervensi, tidak ada unsur permainan oleh sekelompok kekuatan tertentu yang membentuk kartel dan sebagainya. Dalam pasar bebas misalnya, terkadang terjadinya saham yang diperdagangkan dengan perubahan harga yang cukup wajar. Wajar disini berarti fluktuasi harga yang terjadi berlangsung secara normal, tidak ekstrem. Tapi terkadang juga sering memperlihatkan ada saja saham-saham yang harganya bergerak secara ekstrem, naik secara mencolok atau turun secara drastis. Fakta di pasar memang seringkali menunjukkan ada beberapa saham yang mencatat kenaikan harga sangat pesat tanpa didukung oleh informasi yang memadai. Kenaikan harga dapat mencapai di atas $50 \%$ bahkan sampai melebihi $100 \%$ hanya dalam waktu beberapa hari, kurang dari satu bulan. Kenaikan harga 50-100 \% dalam tempo kurang dari satu bulan, tentu merupakan keuntungan yang menawan dan menggiurkan. Memahami mekanisme pasar pada aktifitas jual beli saham di pasar modal ini bukanlah hal yang sederhana. Dibutuhkan kejelian dan kepekaan tinggi untuk melihat mana saham yang memang bergerak berdasarkan mekanisme pasar dan mana saham yang bergerak di luar mekanisme pasar. Disebut bergerak di luar mekanisme pasar karena fakta menunjukkan memang ada saham-saham tertentu yang pergerakannya dikendalikan oleh satu kekuatan tertentu meskipun hal itu sulit dibuktikan. Saham seperti inilah yang harus diwaspadai oleh investor. Bursa Efek Indonesia (BEI) selaku pengawas pasar tidak mungkin mengambil tindakan karena kenaikan harga saham tadi berlangsung dalam koridor pasar. Artinya, tidak ada aturan pasar yang dilanggar. Karena itu investor harus ekstra hati-hati melihat kenaikan harga saham yang tidak didukung oleh fakta material. 
Berbicara mekanisme pasar, ${ }^{23}$ muncul pertanyaan tentang keseimbangan dalam pasar. Ekuilibrium menggambarkan suatu situasi dimana semua kekuatan yang ada dalam pasar, permintaan dan penawaran, berada dalam keadaan seimbang sehingga setiap variabel yang terbentuk di pasar, harga dan kuantitas sudah tidak lagi berubah. Dalam keadaan ini harga dan kuantitas yang diminta akan sama dengan yang ditawarkan sehingga terjadilah transaksi. Selanjutnya, proses terjadinya keseimbangan dalam pasar dapat berawal dari sisi mana saja, baik dari permintaan ataupun penawaran. Adapun perubahan keseimbangan dapat melalui: perubahan berasal dari sisi permintaan. Perubahan berasal dari sisi penawaran. Perubahan berasal dari sisi penawaran dan permintaan ketika berbicara mengenai kesempurnaan pasar maka berikutnya adalah kondisi ketidaksempurnaan bekerjanya pasar. Ketidaksempurnaan pasar dapat dipicu oleh beberapa hal yaitu sebagai berikut: a. Penyimpangan Terstruktur. Struktur atau bentuk organisasi pasar akan mengganggu mekanisme pasar dengan cara yang sistematis dan terstruktur pula. Struktur pasar yang dimaksud adalah monopoli, duopoly, oligopoly, dan kompetisi monopolistik. Misalnya saja dalam monopoli, produsen monopolis bisa saja mematok harga yang tinggi untuk memperoleh keuntungan di atas normal, demikian pula untuk pasar yang lain. b. Penyimpangan Tidak Terstruktur Selain itu juga terdapat faktor-faktor yang insidental dan temporer yang mengganggu mekanisme pasar. Beberapa contohnya adalah usaha sengaja menimbun untuk menghambat pasokan barang agar harga pasar naik (ikhtikar), penciptaan permintaan semu untuk menaikan harga (najasyi), penipuan kualitas, kuantitas, harga, atau waktu pengiriman (tadlis), kolusi para pedagang untuk membuat harga di atas normal (ba'i al-badir lil badi), dan lain-lain. c. Ketidaksempurnaan informasi dan penyesuaian ketidaksempurnaan pasar juga disebabkan karena ketidaksempurnaan informasi yang dimiliki para pelaku pasar. Informasi merupakan hal yang penting sebab ia menjadi dasar bagi pembuatan keputusan. Rasulullah melarang berbagai transaksi yang terjadi dalam ketidaksempurnaan informasi, misal menghalangi transaksi pada harga pasar, mengambil keuntungan yang tinggi dengan memanfaaatkan kebodohan konsumen, dan lain-lain.

23 Adiwarman A. Karim, (2007), Ekonomi Mikro Islami, Ed. 3, Jakarta: Raja Grafindo Persada), hal. 162-163. 
Dalam praktik pasar tersebut secara prinsip pokok masalahnya adalah ketika terjadi ketidaksempurnaan pasar atau penyimpangan dan kemudian bagaimana Islam melihat kondisi seperti ini. Ajaran Islam memberi perhatian yang besar terhadap kesempurnaan mekanisme pasar. Pasar yang bersaing sempurna menghasilkan harga yang adil bagi penjual dan pembeli. Karenanya jika mekanisme pasar terganggu, maka harga yang adil tidak dapat dicapai, begitu pun sebaliknya.

Lebih lanjut konsep mekanisme harga ${ }^{24}$ telah diurai secara rinci dalam kitab Muqaddimah Ibnu Khaldun. Dengan tajam ia membahas tentang terbentuknya harga di Kota. Dalam analisisnya, ia membagi fenomena harga berdasarkan jenis barang menjadi dua, yaitu: (1) barang kebutuhan pokok dan (2) barang pelengkap. Menurutnya, bila suatu kota berkembang dan selanjutnya populasinya bertambah banyak (menjadi kota besar), maka pengadaan barang-barang kebutuhan pokok akan mendapatkan prioritas. "Ketahuilah, semua pasar menyediakan kebutuhan manusia. Di antara kebutuhan itu, ada yang sifatnya harus, yaitu bahan makanan. Ada yang merupakan kebutuhan pelengkap, seperti pakaian, perabot, kendaraan, seluruh gedung dan bangunan. Bila kota luas dan banyak penduduknya, harga kebutuhan pokok murah; dan harga kebutuhan pelengkap mahal”.

Sebaliknya akan terjadi bila orang-orang yang tinggal di kota sedikit dan peradabannya lemah. Sebabnya, karena segala macam biji-bijian merupakan sebagian dari bahan makanan kebutuhan pokok. Karenanya, permintaan akan bahan ini sangat besar. Tak seorangpun melalaikan bahan makanannya sendiri atau bahan makanan keluarganya, baik bulanan atau tahunan. Sehingga usaha untuk mendapatkannya dilakukan oleh seluruh penduduk kota, atau sebagian besar dari pada mereka, baik didalam kota itu sendiri maupun didaerah sekitarnya. Ini tidak dapat dipungkiri. Masing-masing orang, yang berusaha untuk mendapatkan makanan untuk dirinya memiliki surplus besar melebihi kebutuhan diri dan keluarganya. Surplus ini dapat mencukupi kebutuhan sebagian besar penduduk kota itu. Tidak dapat diragukan,

${ }^{24}$ Ibnu Khaldun, Muqaddimah, (Jakarta: Pustaka Firdaus, Edisi Indonesia, 2000). hal. 421423. 
penduduk kota itu memiliki makanan lebih dari kebutuhan mereka. ${ }^{25}$ Akibatnya harga makanan seringkali murah".

Selain itu, Ibnu Khaldun juga memberikan analisis tentang fenomena harga di kota-kota kecil dengan jumlah penduduk yang relatif sedikit, tetapi memunculkan fenomena tingkat harga yang seringkali tinggi. "Di kota-kota kecil dan sedikit penduduknya, bahan makanan sedikit, karena mereka memiliki surplus kerja yang kecil, dan karena melihat kecilnya kota, orangorang khawatir kehabisan makanan. Karenanya, mereka mempertahankan dan menyimpan makanan yang telah mereka miliki. Persediaan itu sangat berharga bagi mereka, dan orang yang mau membelinya haruslah membayar dengan harga yang tinggi." Menurutnya, bila suatu kota berkembang dan populasinya bertambah banyak, maka pengadaan barang-barang kebutuhan pokok menjadi prioritas. ${ }^{26}$ Karena permintaan akan bahan itu sangat besar, tak seorangpun melalaikan bahan makanannya sendiri atau bahan makanan keluarga, bulanan ataupun tahunan. Sehingga usaha untuk mendapatkannya dilakukan oleh seluruh penduduk kota, atau sebagian besar dari pada mereka, baik di dalam kota itu sendiri maupun di daerah sekitarnya, ini tidak dapat dipungkiri.

Masing-masing orang berusaha untuk mendapatkan makanan untuk dirinya sendiri memiliki surplus besar melebihi kebutuhan diri dan keluarganya. Surplus ini dapat mencukupi kebutuhan sebagian besar penduduk kota itu. Tidak dapat diragukan, penduduk kota itu memiliki makanan lebih dari kebutuhan mereka. Akibatnya, harga makanan seringkali menjadi murah. Ibnu Khaldun telah menganalisa secara empiris tentang teori supply and demand dalam masyarakat. Dalam kalimat diatas Ibnu Khaldun secara ekspilisit memformulasikan tentang hukum supply dan kaitannya dengan harga. ${ }^{27}$ Menurutnya apabila sebuah kota berkembang pesat, mengalami kemajuan dan penduduknya padat, maka persediaan bahan makanan pokok melimpah. Hal ini dapat diartikan penawaran meningkat yang berakibat pada murahnya harga barang pokok tersebut. Analisa supply and demand Ibnu Khaldun tersebut dalam ilmu ekonomi modern, diteorikan sebagai terjadinya peningkatan disposable income dari penduduk kota. Naiknya disposible

25 Ibid., hal.421

${ }^{26}$ Adiwarman Karim, Ekonomi Mikro Islami, (Jakarta: Cet. III, 2003), Edisi Kedua, hal. 231. 
income (kelebihan pendapatan) dapat menaikkan marginal propersity to consume (kecendrungan marginal untuk mengkonsumsi) terhadap barang-barang mewah dari setiap penduduk kota tersebut. ${ }^{28}$

Dengan demikian persediaan tidak bisa mencukupi kebutuhan; jumlah pembeli meningkat sekalipun persediaan barang itu sedikit, sedang orang kaya berani membayar tinggi sedangkan kebutuhan mereka makin besar dan ini menyebabkan harga naik. Lebih lanjut Adiwarman Karim sebagaimana dikutip oleh Eny Puji Lestari $^{29}$ mengomentari, bahwa fenomena ini dapat disimpulkan sebagai terjadinya proses peningkatan disposable income (Pendapatan sesudah pajak) ${ }^{30}$ dari penduduk kotakota. Naiknya disposable income dapat meningkatkan marginal propensity to consume (proporsi pendapatan untuk konsumsi) terhadap barang-barang mewah dari penduduk kota tersebut. Hal ini kemudian menciptakan permintaan baru atau peningkatan permintaan terhadap barang-barang mewah. Akibatnya harga barang mewah akan meningkat pula. Kecenderungan mendapatkan kebutuhan pokok dengan harga murah bagi penduduk kota membuat mereka mempunyai kelebihan pendapatan (disposable income) dan normalnya setelah kebutuhan pokok terpenuhi maka manusia cenderung untuk memenuhi kebutuhan pelengkap dan mewah.

Menurut Ibnu Khaldun ${ }^{31}$, bila suatu kota berkembang dan selanjutnya populasinya akan bertambah banyak, maka harga-harga barang kebutuhan pokok akan mendapatkan prioritas pengadaanya. Akibatnya penawaran meningkat dan ini berarti turunnya harga. Sedangkan untuk barang-barang mewah, permintaannya akan meningkat sejalan dengan berkembangnya kota dan berubahnya gaya hidup. Akibatnya harga barang mewah meningkat. Ibnu Khaldun juga menjelaskan mekanisme penawaran dan permintaan dalam menentukan harga keseimbangan. Secara lebih rinci, ia menjabarkan pengaruh persaingan di antara konsumen untuk mendapatkan barang pada sisi permintaan. Setelah itu, pada sisi penawaran ia menjelaskan pula pengaruh meningkatnya biaya produksi karena pajak dan pengutan-

28 Euis Amalia, Sejarah Pemikiran Ekonomi Islam, (Jakarta: Gramata, 2010), hal. 225

${ }^{29}$ Eny Puji Lestari, Adkiya, STAIN Jurai Siwo Lampung, Maret 2015, hal. 10

${ }^{30}$ Cristopher Pass \& Bryan Lowes, Dictionary of Economics, (terjemahan), Jakarta, Erlangga, Cet. II, hal.161 1 Juli 2013

${ }^{31}$ Muhammad, Telaah Bisnis; Tinjanan Sejarah Mekanisme Pasar dalam Islam, Volume 14, Nomor 
pungutan lain di kota tersebut. Pada bagian lain dari bukunya, Ibnu Khaldun menjelaskan pengaruh naik dan turunnya penawaran terhadap harga. Ia mengatakan:

"... When goods (brought from outside) are few and rare, their prices go up. On other hand, when the country is near and the road is safe for travelling, there will be many to transport the goods. Thus they will be found in large quantities, and the price will go down."

Ini menunjukkan bahwa Ibnu Khaldun telah mengindentifikasi kekuatan permintaan dan penawaran sebagai penentu harga keseimbangan. Ibnu Khaldun, kemudian mengatakan bahwa keuntungan yang wajar akan mendorong tumbuhnya perdagangan, sedangkan keuntungan yang sangat rendah akan membuat lesu perdagangan karena pedagang kehilangan motivasi. Sebaliknya, bila pedagang mengambil keuntungan sangat tinggi, juga akan membuat lesu perdagangan karena lemahnya permintaan konsumen. Bila dibandingkan dengan Ibnu taimiyah, yang tidak menggunakan istilah persaingan, Ibn Khaldun menjelaskan secara eksplisit elemen-elemen persaingan. Bahkan ia juga menjelaskan secara eksplisit jenis-jenis biaya yang membentuk penawaran, sedangkan. Ibnu Khaldun juga mengamati fenomena tinggi-rendah, tanpa mengajukan konsep apapun tentang kebijakan kontrol harga. Di sinilah bedanya, tanpaknya Ibnu Khaldun lebih fokus menjelaskan fenomena yang terjadi, sedangkan

Sementara Ibnu Khaldun terus bergerak jauh dari para ekonom konvensional, kemungkinan ia tidak memikirkan grafik penawaran dan permintaan, elastisitas penawaran dan permintaan, dan yang utama adalah keseimbangan harga yang memainkan peranan dalam diskusi ekonomi modern. Ibnu Khaldun juga menyoroti penyebab naiknya biaya produksi yang diakibatkan adanya bea cukai, pajak dan pungutan lainnya sehingga dia berteori bahwa harga barang di padang pasir lebih murah karena tidak mengandung unsur bea cukai, pajak, dan pungutan lain dalam komponen biaya produksinya dibanding harga di kota. Selain dipengaruhi pajak atau bea cukai dan biaya produksi, naik turunnya harga barang dipengaruhi oleh adanya penimbunan. Ibnu Khaldun juga mengupas tentang pengaruh keuntungan wajar terhadap perdagangan. Menurut dia, harga yang terlalu rendah akan menurunkan motivasi produsen untuk bertahan atau masuk ke pasar, 
sedangkan harga yang terlalu tinggi juga akan mengakibatkan kurangnya minat konsumen untuk membeli barang tersebut dan hal ini dapat membuat pasar lesu.

\section{Kesimpulan}

Pasar adalah sebuah mekanisme pertukaran produk baik berupa barang maupun jasa yang alamiah dan telah berlangsung sejak peradaban awal manusia. Islam menempatkan pasar pada kedudukan yang penting dalam perekonomian. Rasulullah sangat menghargai harga yang dibentuk oleh mekanisme pasar sebagai harga yang adil. Beliau menolak adanya suatu intervensi harga seandainya perubahan harga terjadi karena mekanisme pasar yang wajar yaitu hanya karena pergeseran permintaan dan penawaran. Untuk lebih menjamin berjalannya mekanisme pasar secara sempurna, peranan pemerintah sangat penting.

Ibnu Khaldun menjelaskan faktor lain yang dapat membentuk dan mempengaruhi harga suatu komoditas atau barang yaitu pajak. Ibnu Khaldun berusaha menjelaskan bahwasanya harga terbentuk melalui sebuah mekanisme alamiah. Harga bisa terbentuk akibat dari adanya permintaan atas barang dan juga penawaran. Sehingga pungutan dan pajak mempunyai peranan yang mampu menjadi pengatur stabilitas harga.

\section{DAFTAR PUSTAKA}

Agustianto,"Pemikiran Ekonomi Ibnu Khaldun," http://shariaeconomics.wordpress.com /2011/02/26/pemikiran-ekonomiibnu-khaldun/(10 September 2016).

Amalia, Euis, Sejarah Pemikiran Ekonomi Islam, Jakarta: Gramata, 2010.

Anto, MB. Hendrie, Pengantar Ekonomika Mikro Islam, cet.I, Yogyakarta, Ekonisia, 2003.

Antonio, M. Syafi'i, Bank Syariah: Dari Teori ke Praktik, Jakarta, Gema Insani Press, 2001.

Chamid, Nur, Jejak Langkah Sejarah Pemikiran Ekonomi Islam, Jogjakarta : Pustaka Pelajar, 2010. 
Chapra, M. Umer, Masa Depan Ilmu Ekonomi : Sebuah Tinjauan Islam, Jakarta: Gema Insani Press, 2001

Farida, Ulfa Jamilatul,' Telaah Kritis Pemikiran Ekonomi Islam Terbadap Mekanisme Pasar Dalam Konteks Ekonomi Islam Kekinian' dalam La-Riba-Jurnal Ekonomi Islam, Sleman: Universitas Islam Indonesia, 2012.

Faruqi, Ismail R. Al-, The Cultural Atlas of Islam, New York; Mac Millan Publicing Company, 1986.

Hasan, Ali, Manajemen Bisnis Syariah: Kaya di Dunia Terhormat di Akherat, Yogyakarta: Pustaka Pelajar, 2009.

Karim, Adiwarman, Ekonomi Islam: Suatu Kajian Ekonomi Makro, Jakarta, IIIT, 2002.

2007.

Khaldun, Ibnu. Muqaddimah. Terj. Ahmadie Thoha, Jakarta: Pustaka Firdaus, 2000.

Khudhairi, Zainal al-, Filsafat Sejarah Ibn Khaldun, Pent. Ahmad Rafi' Usmani, Bandung: Penerbit Putaka, 1987.

Kotler, Manajemen Pemasaran, (edisi ke sebelas) Jilid 2, Jakarta : Gramedia, 2005.

Lestari, Eny Puji, Adkiya, STAIN Jurai Siwo Lampung, Maret 2015.

Maearif, Ahmad Syafi'i, Ibnu Khaldun dalam Pandangan Penulis Barat dan Timur, Jakarta: Gema Insani Press, 1996

Mahdi, Muhsin, Ibnu Khaldun's Pbilosopby of History, Chicago: The University of Chicago Press, 1971.

Manis, Jim, An Inquiry into the Nature and Causes of the Wealth of Nations by Adam Smith, Hazleton: The Pennsylvania State University, 2005.

Mannan, M. Abdul, Teori dan Praktek Ekonomi Islam, terj. M. Nastangin, Yogyakarta, Dana Bhakti Wakaf, 1995.

Muhammad, Telaah Bisnis; Tinjanan Sejarah Mekanisme Pasar dalam Islam, Volume 14, Nomor 1 Juli 2013

Nasution, Mustafa Edwin, et al., Pengenalan Eksklusif Ekonomi Islam, Jakarta, Kencana Prenada Media Group, 2006.

Pass, Cristopher \& Bryan Lowes, Dictionary of Economics, (terjemahan), Jakarta, Erlangga, Cet II. 
Pusat Pengkajian dan Pengembangan Ekonomi Islam (P3EI), Ekonomi Islam, Jakarta: Rajawali Pers, 2009

Qardhawi, Yusuf, Norma Dan Etika Ekonomi Islam, Jakarta: Gema Insani, 1997.

Rahardjo, M. Dawam, "Menegakekan Syariat Islam di Bidang Ekonomi", dalam Adiwarman Karim, Bank Islam: Analisis Fikih dan Kenangan, cet.I, Jakarta, IIIT, 2003.

Rozalinda, Ekonomi Islam Teori dan Aplikasinya pada Aktivitas Ekonomi, Jakarta: Rajawali Pers, 2014

Rozenthal, Franz, Ibnu Khaldun the Muqaddimah, An Introduction to History, London: Routledge \& Kegan Paul, 1958.

Shihab, M. Quraish, Tafsir al Misbah, Jakarta: Lentera Hati, 2002.

Supryitno, Eko, Ekonomi Islam: Pendekatan Ekonomi Makro Islam dan Konvensional, Yogyakarta, Penerbit Graha Ilmu, 2005.

Syafei, Rachmat, Fiqih Muamalah, Bandung: Pustaka Setia, 2000. 